\title{
"Folklore seeks out the things that are not permitted in official discourse". An Interview with Lillis Ó Laoire
}

\author{
José Francisco Fernández \\ University of Almería, Spain
}

Copyright (c) 2020 by José Francisco Fernández. This text may be archived and redistributed both in electronic form and in hard copy, provided that the author and journal are properly cited and no fee is charged for access.

\begin{abstract}
Lillis Ó Laoire is a sean-nós singer and lecturer in the School of Languages, NUI Galway. He is a Donegal native and a graduate of NUI Galway and of University College Cork. He has been a visiting Professor at Loyola Marymount University, Los Angeles. He has co-authored a book (with Seán Williams) on the great Connemara singer Joe Heaney, Bright Star of the West (Oxford UP, 2011). His research interests include Gaelic song traditions and history, performance and transmission of folklore, ecocriticism and ethnomusicology. As a scholar, he has published articles in Journal of Rural Studies, Folk Life: Journal of Ethnological Studies and in the American Journal of Irish Studies, among other specialized journals. This interview took place in January 2019 at NUI Galway, where he teaches Irish language, folklore and Celtic Civilisation.
\end{abstract}

Key Words. Irish Folklore, Peig Sayers, Irish Language, Celtic Civilisation.

Resumen. Lillis Ó Laoire es un cantante de música tradicional irlandesa y además imparte docencia en la School of Languages de la Universidad de Galway. Ó Laoire procede de Donegal y cursó sus estudios universitarios en las Universidades de Galway y de Cork. Asimismo, ha sido profesor visitante en la Universidad Loyola Marymount, de Los Ángeles, EEUU. Es coautor del libro Bright Star of the West (Oxford UP, 2011), escrito junto con Seán Williams, y que versa sobre el famoso cantante de Connemara, Joe Heaney. Sus intereses como investigador se centran en la tradición y en la historia de las canciones en gaélico, así como en la ejecución y la transmisión del folclore, el ecocritisimo y la etnomusicología. Como investigador ha publicado artículos en revistas especializadas como Journal of Rural Studies, Folk Life: Journal of Ethnological Studies y en American Journal of Irish Studies. Esta entrevista tuvo lugar en la Universidad de Galway en enero de 2019, donde Ó Laoire da clases de idioma irlandés, folclore y civilización celta.

Palabras clave. Folclore irlandés, Peig Sayers, idioma irlandés, civilización celta. 
José Francisco Fernández: There are many departments in universities all over the world, like the one in UCD, Dublin, which contain vast amounts of archive material on Irish folklore collected by experts over many decades. Would you say Irish folklore is one of the best preserved in the world?

Lillis Ó Laoire: I'm not able to say that fully. I know that there are very substantial archives elsewhere, in Scandinavia for example, but yes, the National Folklore Collection in UCD numbers among the largest folklore archives in the world. The collection started systematically in the 1930s with the Irish Folklore Commission. There was an Irish Folklore Institute before that. Other collections were also previously made less systematically and there are other holdings as well that don't have to do with the Field Work project that began in 1935. So there is a very substantial body of Irish folklore in various archives. The National Folklore Collection is unique, however, because of the systematic and continuous nature of the collecting effort over more than a thirty five year period.

\section{JFF: How would you assess the work on this project by the Irish Folklore Commission? I understand that it ended in 1971.}

LÓL: The Folklore Commission ended in 1971, with the establishment of the Department of Irish Folklore at UCD, but collecting continued even after that and other work, such as transcription, continued after that, including people I knew well. My own mentor, Seán Ó hEochaidh, he was a collector himself, he was a friend of our family in Donegal, and he continued to work until 1985, even though he was well beyond the age of retirement. He continued to transcribe audio recordings for the Commission or for the Department and to review other materials after 1971. Collecting still continues, even though the collecting now is not as extensive as it once was. There is also now the Irish Traditional Music Archive, which has a very active collection programme. RTE, the national broadcaster also has substantial sound and other archives. Since 1972 with the establishment of Raidió na Gaeltachta, these have increased immensely. Cataloguing continues but could do with greater investment. The IFC amassed large archives with few enough resources in a financially hostile environment where its work was frequently misunderstood. This archive remains a crucially important cultural resource.

\section{JFF: What is the practical use of this material?}

LÓL: This is an interesting question. Patrick Kavanagh famously described the Schools' Collection, created in 1937-38 now online at www.duchas.ie, as 23 tons of useless folklore. By talking about the research conducted using the archive one can estimate its value. The great study by Máire MacNeill, The Festival of Lughnasa, for example, inspired Brian Friel's play Dancing At Lughnasa, later made into a feature film of the same name. In fact, printed in the programme for the play was the story from MacNeill's book, collected in Donegal that had inspired him most. It was told by Máire Nic Pháidín, an octogenarian who had spent a good part of her life in Australia. I don't know if writing a book about a calendar festival is "practical" or whether the writing and performance of a play can be considered "practical," but both works have certainly enriched the lives of readers and audiences. How can you measure that practically?

There are other such fascinating studies based on the materials in the IFC such as Patricia Lysaght's study of the Banshee, Angela Bourke's study of the oral poetry of the Christian Passion and Gearóid Crualaoich's work on the Cailleach to name only a few. My own students have worked on different projects. One student has studied folk tales and tellers 
from the Joyce Country of North West Galway. She relates the folktales to the lives of the tellers and she shows conclusively that narrators were really actively engaged in sourcing their own material. Some were Irish-speaking migrants and worked in England in industrial settings. They taught themselves to read English. Some of them hadn't attended school, but by persevering they began to read stories in books and then to translate them into Irish and tell them to the audiences at home. There is a famous episode where an American folklore collector, Stith Thompson, came to visit the Director of the Irish Folklore Commission, James H. Delargy, and they got one of these storytellers, Micheál Breathnach, from Mám in County Galway, to tell a story learned from a book which wasn't known to be found in Ireland. The American thought, "This is a great new discovery!" They let him in on the prank afterwards, however. Folktales and legends cast a very interesting light on cultural attitudes to gender and sexuality, as Freud and Jung both knew. From a psychological point of view a knowledge of them could have practical benefits as Gearóid Ó Crualaoich has shown in The Book of the Cailleach.

\section{JFF: Do you think the archive material may act as a kind of reminder for the audiences, a reminder of where they come from?}

LÓL: Certainly, there is a lot of memory inscribed in archive material and crucially it records the memory of people who would have remained anonymous and whose voices otherwise would have not been heard. Folklore deliberately seeks the unofficial, the popular, the subaltern voice. It is drawn to the superstitious if you like, seeking out the things that are not permitted in official discourse. That is one way of looking at that archive. Folklore is a kind of knowledge. The way it is viewed and interpreted is an essential component of it. It is a system and has to be understood as such. The knowledge is often contained in poetic or metaphorical expression, such as short narratives, rhymes and proverbs, as well as in longer stories and songs. This is how oral knowledge is transmitted and is what Lévi Strauss meant when the discussed the "savage mind."

One proverb I like is "dá chrua an chloch, déanfaidh an duirling cruinn í," - no matter how hard the stone, the cobbles will round it. It's a very specific environmental reference to a duirling or doirling - part of the shore where rounded stones are found together, a cobble beach. Shaped by their rubbing against each other during the ebb and flow of the tide, they take on the appearance of eggs. In one interpretation, the proverb refers to life in a close-knit community and suggests that despite how adamant the opinions may be, people have to be able to reach consensus in order to live together harmoniously and smoothly. The phrase combines a cool, elegant detachment with acute observation of the natural environment.

Another way of looking at archive materials is through the lense of the ideologies that influenced the collectors as they worked. There was nationalism, there was consideration of religion, there was gender bias, as most of the full time collectors were men, there were sexual mores, there were all sort of topics people didn't want to, or were reticent to talk about. Although in some ways it is very comprehensive, it's a partial archive. Such discursive elements permeate it, so that it is a reflection of its time and its creators.

\section{JFF: Do people like to be told where they come from?}

LÓL: The public does want to know, yes. There is tremendous interest now, for example, in DNA sampling and the ways in which it can help trace ancestry. Likewise, when the Census returns of 1901 and 1911 became available online, people responded with immense enthusiam. This impulse is an age old one. As we become more urbanised, as we move away from our rural backgrounds, there is a yearning to look back and see how just two generations 
ago the people lived. Compared to the present, Ireland then was a much poorer country. Some people will undoubtedly be uninterested in where they come from, others will want to forget, but there is always a considerable group of people who want to know about their personal histories. Scholars have a duty to remind people, and to bring forward things that have been forgotten, to put the present in perspective, especially with the arrogance that often comes with affluence, the kind of hubris that accompanies material comfort. Present debates about immigration provide an interesting case. Ireland was and remains a society of migrants, though ideologies of the right wish to plead a special case for historical Irish emigration, radically separating it from present immigration to Ireland. Analysis of folk memory and other sources can help destablize such misguided narratives.

\section{JFF: If tonight I go to a pub here in Galway and there is some live music, am $I$ in touch at that moment with Irish folklore?}

LÓL: Yes, you are.

\section{JFF: And would you make a distinction in terms of authenticity between folklore in theatres or festivals and the music that is played every night in pubs?}

LÓL: "Authenticity" is an ideologically saturated concept and can be incredibly reductive, imposed by the Romantic movement, as Regina Bendix has shown. At present, it's unsustainable. Life changes and traditions must change with it. Idealising a golden age that supposedly existed before modernity is a mistake. One of Gadamer's ideas is that all action is authentic, augmenting and extending that of preceding generations. That's a flexible and inclusive perspective, one that reflects my own experience. I think there is a continuum between older rural ways of performance and modern urbanized approaches, rather than separate entities. The process of history unfolding in everyday life is always continuing and the ideological movements that have shaped culture in Ireland have also influenced popular culture in different ways. The revival of literature, culture, music, and generally a consciousness that Irishness is a separate kind of expression from a general anglophone identity emerged, in its most effective form, at the turn of the 20th century. It was accompanied by a nationalist movement for independence. And these factors have definitely influenced the fact that people play music in pubs now, because it was the way to hear Irish music as well at that time. Such ideas were consolidated by the establishment of Comhaltas Ceoltóirí Éireann in 1951, a musicians' organization that runs local county, provincial and national and international competitions culminating in the annual Fleadh Cheoil na hÉireann, in a manner not unlike the GAA since that time. Music has been codified, it's being widely taught and promoted. More people are playing it. Today it is a more popular and relatively democratic movement whereas in the past it was confined to particular families. Perhaps it wasn't entirely a respectable thing, and some considered it a sort of inferior music, because there was this dichotomy between formal music learned through official means and music learned at home from family. Increasingly now, however, among people who play music there is a lot of blending and melding of different traditions. People go to the classical repertoire, people play both repertoires and use the historical collections. Some of the most famous fiddle players have studied classical music and at one time they made a choice between one or the other. Other musicians don't make that choice, they move between them. Gamelan performance and its accompanying dance in Bali has been criticized because it is now "just for tourists." But the musicians counter that tourists provide them with income and contribute to the continuing vitality of traditional arts. Bab Feiritéar, the great Kerry storyteller, from Dún Chaoin, found new audiences among language learners in the late fifties and early sixties 
as traditional winter house visiting declined. She was no less of an artist because of that. Her son Breandán, a prolific broadcaster, became a filmmaker, and views his work as a direct continuation of traditional storytelling. I advised a student of mine, Seanán Mac Aoidh, who was studying storytelling to learn how to narrate stories as a way of deepening his research. He has now emerged as a performer of stories and is much in demand. One of the best storytellers in Donegal today, Eithne Ní Ghallchobhair, has a Ph.D. in medieval literature and is a published writer of modern short stories. I think that these other talents probably enhance rather than hinder her accomplishment.

\section{JFF: What is your opinion about the way folklore has been taught in schools? There is this famous book, Peig, by Peig Sayers, which was compulsory reading, wasn't it?}

LÓL: This book was considered to be compulsory, but actually it was formally never compulsory. It was a prescribed text but not the only one. Teachers could choose which texts they would read with their students. Teachers probably chose it because it was among the few books that represented the female experience. Therefore, it was widely prescribed for girls to read. But it is important to remember that there was choice about which texts to study. I studied four main prose texts for my Leaving Certificate but Peig was not among them. Our teacher chose other books.

Peig is a Blasket Islands autobiography and it is a very interesting case because Peig Sayers was literate but only in English. She could not write her own story in the Irish language, so her story was written down by others. There are actually three versions of that autobiography. The one put on the school curriculum was absolutely ridiculed and spurned by many of those who read it, because it seemed to depict the woman as a victim, a sort of mater dolorosa. It seems odd to me that women in late middle age can still become angry about having had to read Peig. I would have thought that life might have given them some sense of perspective on another woman's story.

Peig led a very hard life. She lost almost all her children to accidents, illness or emigration to the US. She had dearly wished to go to the States herself, but her friend Cáit $\mathrm{Jim}$, for one reason or another, was unable to send her the passage money. Without a dowry, she married a Blasket Islander to escape the drudgery of service and her unsympathetic sister in law, who was the ranking female in her home and who did not want Peig as a dependent. Her husband died when she was relatively young, leaving her alone at the end of her life. One son, Maidhc, who was briefly in the States too, returned and remained with her.

To emphasize this undoubted hardship to the exclusion of other experiences, presents a very reduced picture of a life expressed by an extraordinary story-telling talent. The story as given in schools doesn't do her oeuvre justice. It deliberately tried to present a conservative male view of Irish female existence in life and the women who read this book, who thought it was compulsory because of the choice of their teacher, rejected that vision of life as a model for themselves. They were perfectly justified in doing that, but in rebelling against it, they blamed Peig as a woman for a whole concatenation of circumstances that Peig had very little to do with. By so doing, they repudiated so much else that was interesting and vibrant and lively. My own teacher and colleague, Pádraig Ó Héalaí, is completing a major edition of Peig's works now. With the late Bo Almqvist, he published a volume of Peig's sound recordings in 2009, Labharfad le Cách/ I Will Speak to you All. It's a very interesting book with a very accessible essay assessing Peig's work. This is part of a whole revisionist movement trying to rehabilitate Peig's life, to take it out of that narrow didactic context. 


\section{JFF: If you were in charge of drafting the list of books related to Irish folklore for the National Curriculum, which other titles would you include in the list?}

LÓL: I would put selections from Peig on the curriculum, because some of the adventures that Peig reports are really fun, there is a lot of amusement in them, she was an amusing woman, such as the time she was hungry and broke into the pantry to get something to eat, successfully outwitting her miserly employer in the process. People gravitated to her in the island, her house as a widow was free, and people would go there for entertainment and they loved to hear her talking, she was a spell-binding narrator.

Another book from the Blasket Islands is called Twenty Years A-Growing, by Maurice O'Sullivan. I would include little pieces from this biography of a young man growing up in Ireland, and there are others from Donegal. I would put selections from Seán Ó Conaill and from Micí Mac Gabhann's work on the curriculum, some folktales and some fairy legends. In fairness, some of these items were on the curriculum in the past. Some urban folklore would also be good.

\section{JFF: The Irish language is mandatory in schools until the age of 17 . What are your thoughts on this?}

LÓL: Mathematics and English are also mandatory until the Leaving Certificate. Many students are now 18 or even 19 because of transition year. Unless you want to study either English or Mathematics at University, it would seem to me that you have a sufficient grasp of them by age 16 to do you for the rest of your life. You will continue to use English and your literacy will continue to develop. Many people say that 'Irish was shoved down their throats.' This is a reflection on a rather constrictive and restrictive regime in most schools in the past, for which Irish seems to get more than its share of blame. Lack of enjoyment can have many causes: a poor teacher, an uninteresting curriculum, lack of personal interest, lack of support for the subject in the school, reflecting at best a lukewarm if not outright hostile attitude among some groups in society generally. There were elements of the English curriculum for the senior cycle that I did not enjoy and certainly Maths was never top of my favourites list. But I sucked it up and got on with it. It didn't occur to me to question its validity because I did not enjoy it.

Mandatory Irish is controversial for some people although there are also large numbers who support it. I am conflicted about that because, on the one hand, I don't like the fact that some resent having to study something against their will. But, then, as I have mentioned, English and Mathematics are also compulsory. As a protective measure, the position of Irish in the education system is of central importance. I can't see that Irish would otherwise survive in the utilitarian education system. So the argument for giving everyone the opportunity to study the language is about citizenship and cultural formation. Irish, a language that developed and grew on this island and was created over generations by people who lived through it and used it, forms part of our distinctive identity. This is found in the Irish language. That is, you can be as Irish as anybody else when you speak English, but to have the opportunity to study the Irish language and Irish culture gives you additional value, and I think that everyone deserves the opportunity for that. Séamus Heaney made a powerful statement about the effect of not learning Irish - it has become a meme on social media. The recent book A History of Ireland in a Hundred Words (Arbuthnot, Ní Mhaonaigh \& Toner 2019) is proving very popular and shows the interest people have in Irish when it presented in a popular, accessible fashion backed up by excellent scholarship. The authors rightly point out that Irish has been spoken in Ireland as a majority language for far longer than English, which has really only gained precedence since about 1800 . 
Irish is very well taught in some schools, in others poorly taught by people who are not themselves very enthusiastic about it. I find the construction of post-colonial studies in the Anglosphere interesting in that it tends to marginalize indigenous or colonized languages. It tacitly imagines that in post-colonial studies everyone can be content with citizenship in that monoglossic universe, working out their post-colonial trauma in crisp, well-written English. Irish has a lot of baggage, much of it inherited from its historical repression. Richard Murphy, the poet, whose father had been Mayor of Colombo, tells that kaduwa, the word for sword in Sinhala, a language of Sri Lanka, is also used idiomatically for the English language, "a commanding, oppressive, fearsome tongue," as Murphy says (2002: 349).

Many people agree with the utilitarian view that Irish is useless. They feel that studying Chinese or Spanish or another language will be more "useful." I am not against studying Chinese or Spanish. Quite the contrary, the more languages the better. For me, Irish makes Ireland. To study the indigenous language of the country whose citizenship you hold, and to study it well, has to be inherently beneficial, despite the admitted challenges in the system. It's a radical act of decoloniality, although this impulse is distinctly muted because it is at the core of the curriculum, so that it appears to have a privileged position. Undoubtedly, some people reject a decolonial reconfiguration of identity. That debate preceded independence and did not end after it. One problem, among many others, arises because it's used so little publicly that people often don't have the context for use outside of the educational system. When they leave the system, their Irish atrophies. But trying to get the State to provide services for Irish speakers is like trying to get blood from a turnip, although some improvement has happened in recent years. On the other hand, Irish may be seen as a very respectable middle class accomplishment, once used as a way to advance through the state system, which gave advantages to those who had competence in Irish. As an official language of the state, then, it could be said to represent a conservative position. However, the apparatus that supported the state promotion of the Irish language has been steadily dismantled over the last forty years. Very few civil servants are now competent to provide service in the Irish language, and there are no longer any extra advantages to knowing it. Parents in new communities throughout the state, however, and despite the discouragement of the Department of Education and Skills, continue to demand Irish medium education for their children. A counterdiscourse to this suggests that it's a way to keep out immigrants and people of colour. However, many immigrants have learned Irish successfully because they are already multilingual when they arrive in Ireland, and Irish becomes just another language to be learned. The activist group Misneach, confronts state hypocrisy around the Irish language, campaigning for government to treat the Irish language as an official language beyond just the tokenistic ritual uses that too often replace true recognition.

\section{JFF: Let's imagine that you are appointed Minister of Education in Ireland and that you have the possibility of improving the way Irish is taught at school. Which measures would you implement?}

LÓL: I would try to improve the teaching. I would try to ensure that only seriously enthusiastic individuals with high competence would be teachers. I would try to change the curriculum to make it more dynamic. This would create opportunities to learn and to be fluent in Irish and to create situations where pupils could do that. There is the residence idea, going back to the first revival, where people go to Irish-speaking areas to be immersed in the language. I would incentivize such journeys by providing financial supports to those wishing to go for immersion. For those studying for a degree, immersion would be mandatory. It would be an experience rather than a classroom, and I would try to get those on the programme actually to go out and work in their traditional contexts, hay making, going to the 
bog... that sort of thing. It's not just leisure, it is a practical application where people could experience the relationship between the environment and the language in a way that affects their own lives. In our own undergraduate degree, now a four year programme, the first cohort have completed the "Gaeltacht semester or Erasmus" for the first time. They are coming back more confident about their linguistic abilities because they have used the language in everyday settings for a constant period. It has been a very positive development.

\section{JFF: Was folklore used politically in the past to support a particular ideology?}

LÓL: I would mention Peig again, that is the school text. It harboured a political motive in that it promoted the idea that women were created to have hard lives, to suffer and that they had to learn to endure those conditions. Reactionary forces came prominently to the fore at the establishment of the State in the twenties and remained powerful until the late eighties. They still exist but do not enjoy the power they once wielded. In the late nineties, at the annual Blasket Centre conference in West Kerry, Professor Patricia Coughlan gave a paper about Peig and her attitude to life as a woman. The presentation took a major step in rehabilitating Peig's image based on close readings of Peig's works. But it brought quite a strong reaction. The matter was discussed in Morning Ireland, the National Broadcaster's morning radio news Programme. Some claimed that Coughlan had attributed feminism to Peig, as if this was somehow inherently offensive. In her response, Professor Coughlan countered that what she had conducted was a feminist reading of Peig's works, a perfectly reasonable endeavour. She showed that Peig had opinions and views, that she was not this cardboard cut-out, a sort of flat character, accepting all her suffering with an uncritical attitude of Christian resignation. On the contrary, Coughlan showed conclusively that Peig was fully human and that she had things to say about any number of issues nobody had ever thought to associate with her. So, yes, conservative forces sought to use folklore in particular ways to assert social control. Diarmuid Ó Giolláin, Stiofán Ó Cadhla and Micheál Briody have written very effectively about this matter. Ó Cadhla in particular has written about the range of conservative ideologies that have tried to appropriate folklore, but considers that folklore has eluded them all and that it can reconfigure itself again by asking different questions of it. Máirtín Ó Cadhain (1906-1970), a prolific collector of folklore in his own right, was very critical of an official discourse that cast folklore as an expiring medieval phenomenon steeped in piety and illiteracy. He referred to it pointedly as "an t-olagón Duileargúil" - the Delargean lamentation, aiming his barb at the Director of the Irish Folklore Commission. He saw exactly what was happening and opposed it steadfastly in his social and political activism and his imaginative endeavour, creating, for example, an anti-Peig character in the persona of Caitríona Pháidín, who functions, as I argue in a forthcoming paper, in a sense, as "leathchúpla nimheanta Pheig" - Peig's evil twin.

\section{JFF: And in recent years, what would you say about the connection between folklore and politics?}

LÓL: Our identity as a nation as a political entity seems less insecure now, especially when compared to recent events related to Brexit in Britain. Folklore was certainly used to form the image of a distinctive nation in the past. Now, when there are official guests coming to Ireland there is always music. Perhaps sometimes that culture is displayed merely as a decoration, really, an aesthetic add-on rather than a dynamic energy that can revitalize society. One thing that I really like is the egalitarianism of popular culture, how when you go to the pub, as you mentioned earlier, anyone can join in, anyone can be part of it, whether they are a performer or not, they can listen to the music, they can ask the musicians 
questions... That is what people love about Irish culture and the pub is quite central. It's not that there isn't etiquette, but rather that there is a sense of welcome and hospitality, two fundamentals in Irish culture. Sport provides another example. I have known people who have come to Ireland just to be in a pub during a rugby match, or another sporting event, so as to hear the banter and enjoy the cameraderie of those assembled in the place and to participate in that warm feeling of association that people derive from being together, during the feeling of unity generated when the national team is playing an international match. That is something the Irish seem to do well.

\section{JFF: Which novelists have approached folklore in a fruitful and productive way? Which writers would you recommend in that area?}

LÓL: Eilís Ní Dhuibhne would certainly be someone who has used folklore, not in everything that she writes, but she has a $\mathrm{PhD}$ in folklore! Her writing is very diverse. She attributes some of her skill as a writer to her deep study of folk tales and legend. For example, I know she has one play that she wrote in the Irish language called "Dún na mBan Trí Thine"/The Women's Fort is on Fire, which is the name of a legend also known as "The Fairy Hill is on Fire." Originally performed in the 1990s a revised, updated version was performed very successfully at the Galway International Arts Festival in 2018. It is a feminist play focussing on a woman, Lennie, trying to have a career, raise children and be a wife and a home-maker. Because of tensions and insecurities between herself and her husband, arguments and conflicts emerge. The play draws on folk legends, the legend of the changeling, the legend of the milk-stealing hare and the legend of fairy women who come to abduct the solitary housewife, because she has not been able to accomplish all her household tasks in time. The play is very funny, using legend to reveal the main character's unconscious fears and worries.

Another writer, Celia de Fréine, has a poetry collection called Fiacha Fola which has been recently published in English as Blood Debts. It is about the Hepatitis C scandal, when a number of women who needed certain blood products to help them during their pregnancy were given by the state blood bags that were contaminated, but they didn't do anything to stop it, and Celia has written this fantastic collection of poems about the experience of one woman over 20 years. She had been to the doctor and nobody could identify her illness and she hears on the radio the story breaking in the 1990s and she is vindicated finally, it's a very good collection. Celia is using the tropes of popular culture and folklore very much to show that society cannot stigmatise a particular group and that the kind of corruption that led to that situation cannot be tolerated. I was delighted to publish a paper on that, "The Chalice of my Blood. Stigmatized Female Identity in Celia de Fréine's Fiacha Fola" (University of Coimbra, 2017), because you can see that folklore is much alive. I mentioned Brian Friel's interest in folklore earlier and I can also mention John B. Keane's extensive use of seanchas. Folklore is still very much alive in Ireland and part of everyday discourse, though it has of course changed. It is a mistake to link folklore only with the rural and with the past. Kevin C. Kearns' great work on Dublin City folklore proves that conclusively and The Cork Folklore Project, headed by Clíona O'Carroll at UCC, focuses on Cork city lore. Recently also, Michael Fortune of Wexford has been collecting and broadcasting Folklore on social media, showing the great wealth of narrative that still continues to be told by people in Ireland.

The recent attempt to commemorate the RIC, and especially the group known as the Black and Tans, suggests a very lively folk memory, one that completely rejected the poorly managed government move to commemorate this organization, resulting in its "postponement." The Dominic Behan song, "Come Out Ye Black and Tans," recorded by the Wolf Tones, topped the download charts in the aftermath of the affair. The group then announced that the proceeds from this spike in popularity would be donated to the Peter 
McVerry trust, making a very salient comment on the government's management of the housing crisis, and the resulting homelessness experienced by many people in the last number of years.

Another interesting critique of government in a folk idiom is the new song by Eoghan Ó Ceannabháin, "My Lovely Leo," a People Before Profit candidate in the 2020 election. It's a very clever, well made song, trenchantly criticising the Taoiseach and, by implication, his party, for his lack of sufficient awareness of and concern for the less well off in society, a humorous accusation that this government has favoured prosperous élites at the expense of those most in need. https://eoghanoceannabhain.bandcamp.com/releases

\section{JFF: You teach a course on Celtic Civilization. How do you approach the teaching of this subject?}

LÓL: First of all, I problematise the term "Celtic" as a word that was used by classical writers to describe people beyond their area of influence, beyond their own borders, they called them Celts, and as time moved on people added other things to that category so that the whole idea of La Tène culture, which is named after a place in Switzerland because the kind of design that is found in that area is also found in other areas of Europe, is described as Celtic. I problematise that, I say how it became Celtimania in the 19th century, the fascination of the primitive and all of that. And then we return to the stories, so we read the story of Cath Muige Tured (The Battle of Moytura), which is an exemplary myth for Middle-Ages Ireland because it explains the characteristics of the ideal king and how one king transgresses those ideals and is therefore deposed. The role of the poet as an political arbiter is prominent here. In a research paper, some years ago, I compared the portrayal of the social contract in CMT with that in the Pied Piper of Hamelin. Because of the current financial situation I read both stories as a trenchant critique of austerity - a tyrannical reneging on the social contract in fact. The concept of the reciprocal culture of the gift supports this argument. That idea was and remains central to the political economy of Ireland, in that politicians are considered as those who are mandated to provide, and then they receive their reciprocal benefit when people vote for them.

\section{JFF: So your approach is far from considering it an extinguished civilization.}

LÓL: These tropes continue and modify what we call democracy now. It is a participative and dynamic political culture, when you think about Celtic idea of kingship. The monarch gathered all the tribute and then he re-distributed it. It is similar to the concept of the potlatch that Marcel Mauss wrote about in his seminal text The Gift. The native chiefs in the North West coast in America would gather a store of wealth for months or even years and then in one, big extravagant gesture they would re-distribute them among their people in order to gain prestige. The poorer they were after the party, the more status they enjoyed. All the wealth they had given away increased their political influence. The competition was so great between chiefs that the colonial authorities banned potlatch. It is recently being reanimated as a custom. And such ideas can be seen central in Irish mythology, ideologies that still inform Irish life in significant ways.

JFF: I cannot finish this interview without asking about your activity as a sean-nós singer. You are a scholar who teaches and does research and writes papers on Irish folklore, and you are also a performer. How do you reconcile those two facets of your life? 
LÓL: There is an element of continuation between both parts and there is also an element of separation. It is a paradox in some respects, not because there needs to be that separation, but I think the academy can be quite conservative and cannot always understand or appreciate the approach of the practitioner. If you write a collection of poetry or a novel for instance, it is unlikely you will get the same credit for it as for an academic paper, unless your contract states that you are employed as a creative writer. You have to produce the papers, you have to go to the conferences. Those activities gain recognition, pointing to a mastery of critical thought and endeavour. However, sometimes creative practice seems more difficult to acknowledge. I am therefore delighted that I have received the TG4 award for Amhránaí na Bliana - Traditional Singer of the Year, bestowed by an independent jury who are closely involved in traditional music.

I was influenced very much in becoming a performer by a professor who was a musicologist himself, Breandán Ó Madagáin, who died in January 2020, in the 1980s and 1990s. He encouraged me to read an American ethnomusicologist, Mantle Hood, who had been at UCLA. He promoted the idea of bimusicality. In his view, students of western music could learn another musical culture, in this case, Indonesian, by learning to perform its music authentically. There was a gamelan orchestra at UCLA so that students could learn to perform the music correctly by playing the instruments. Experts from Indonesia were brought in to teach the correct ways of doing things. This was a heuristic method, learning by doing. I set myself the task of achieving a practical mastery of traditional Gaelic singing. At one point I said to another singer and mentor of mine, Caitlín Ní Dhomhnaill, (1940-1995) that I had made a big effort to master this style and she replied: "Agus anois tá sé déanta agat!" - And now you have done it. I felt very happy when she made that remark.

Thanks to a scholarship from the Fulbright Commission, I had the pleasure to study at UCLA in the 1990s as I worked on my Ph.D. That all came because of my academic and practical interest in song performance and I did a lot of performing with musician friends in the US when I lived there and learned a lot about performing for people who were not necessarily that knowledgable about Irish traditional music, or even about Ireland. I met welleducated people there who said that, before meeting me, they had thought that "Irish" was the way Irish people spoke English!

\section{JFF: Tell me more about your musical activity. When do you sing? Do you do gigs?}

LÓL: I go to events all the time. I went to London early in 2019 for a presentation that included talking and singing about my own research practice and the work I have done over the years. I did something similar in Nijmegen in 2018 at the IASIL conference and there were many people open to it who appreciated it and were very familiar with that kind of approach. I go to small festivals as well. I would like to do another recording, I would try to find the time for that, it is becoming a priority now.

\section{JFF: Do you perform in class?}

LÓL: Yes, students love it! It is a break from chalk and talk, if you like, from someone going on and on and on. In one elective module I make the students sing as a group in class and this forms a core part of the pedagogy. The last class of the day on Wednesdays from 4 to 5 provides a good time to break from the standard lecture format. They learn a mix of songs, some with big melodies and they also love singing the light-hearted music, it cheers them up after a long day. In 2019, I found that they entered strongly into the spirit of things and that they supported each other in deeply affirming ways. This kind of outcome is very welcome. It generates the spark for research, for engagement. There is that dynamic of appropriation, so 
you appropriate first and then you ask yourself what has happened. You stand back from the work and say, now I can analyse it because of the experience of that embodied act. The song lives in them and they feel it in the body. I found it difficult to find a theoretical expression for this for a long time, but now, I consider this as a move toward what Walter Mignolo and Lewis Gordon call "epistemic disobedience," a small gesture that subverts an academic paradigm of eternal analysis and replaces it with the idea that a measure of practical mastery takes a necessary first step to an intellectual consideration of any body of material.

\section{Works Cited}

Murphy, Richard. The Kick. A Life among Writers. London: Granta, 2002.

Ó Laoire, Lillis. "The Chalice of my Blood. Stigmatized Female Identity in Celia de Fréine's Fiacha Fola". Identity (ies): A Multicultural and Multidisciplinary Approach. Ed. Ana Paula Arnaut. Coimbra: University of Coimbra Press, 2017. 189-208.

Received: 1 November 2019 Revised version accepted: 22 January 2020

José Francisco Fernández is Senior Lecturer in English literature at the University of Almería, Spain. His most recent work focuses on the narrative of Samuel Beckett and his reception in Spain, including articles on Beckett published in specialized journals such as Journal of the Short Story in English, Journal of Beckett Studies, AUMLA, Studi Irlandesi and Arcadia, among others. He has also translated into Spanish three novels and three short stories by Samuel Beckett. His translation of Texts for Nothing was awarded with the AEDEAN translation prize in 2016. He teaches Anglo-Irish literature in the Master's Degree in English Studies at the National University of Distance Education (UNED) and is general editor of the journal Estudios Irlandeses.

jffernan@ual.es 